\title{
Risk insights vs. competences in managing multicultural teams in Poland
}

\author{
Ludmiła Walaszczyk, Remigiusz Mazur
}

\begin{abstract}
A B S T R A C T
Objective: The objective of this study was to obtain in-depth understanding of the concept of necessary competences, which could ensure effective work in multicultural organisations based on different risks, which can occur in practice.

Research Design \& Methods: The authors made in-depth literature review in order to identify and to understand the possible risks that can occur in multicultural organisations and the behaviours of staff related to the risks identified. Afterwards, the authors made interviews with 30 people from multicultural organisations in order to finally present a qualitative analysis, which aimed at identifying and comparing competences, which seem to be necessary in order to work effectively in multicultural organisations.

Findings: Based on the feedback from the target groups, it turned out that the respondents admitted that it is necessary to have specific competences, which could support effective works in the multicultural organisation.
\end{abstract}

Contribution \& Value Added: The core input is that the results of the study are not be only the subject of theoretical considerations, but they can be implemented in practice in the form of a dedicated training.

\begin{tabular}{ll}
\hline Article type: & research article \\
& multiculturality; cultural risk; cultural competences; intercultural \\
Keywords: & management; cultural awareness of staff
\end{tabular}

JEL codes: $\quad$ D22, J24, J61

Article received: 11 June 2019

Article accepted: 31 July 2019

\section{Suggested citation:}

Walaszczyk, L., \& Mazur, R. (2019). Risk insights vs. competences in managing multicultural teams in Poland. International Entrepreneurship Review (previously published as International Entrepreneurship | Przedsiębiorczość Międzynarodowa), 5(3), 145-162. https://doi.org/10.15678/IER.2019.0503.10

\section{INTRODUCTION}

In global economy, many enterprises of different size operate in multicultural environments, whether in dealing with clients or within their own workforces. Multinational working today necessarily involves establishing collaborative partnerships for the delivery of goods and services, and employees across the EU are increasingly required to 
operate in a way, which demonstrates sensitivity and competence in dealing with people from different cultural backgrounds.

Nowadays, when the borders are opened, there is a strong need to focus on intercultural dialogue between people, who work together (e.g. Angouri \& Glynos, 2009; Besley \& Peters, 2012; Bikmen \& Sunar, 2013; Choi, 2006; Lähdesmäki \& Wagener, 2015; Wilk-Wos, 2010). Developing cultural competences results in an ability to understand, communicate with, and effectively interact with people across cultures, and work with varying cultural beliefs and schedules. However, people from different cultures vary in how, for example, they relate to many aspects. As the example of perceiving the term 'bad news' (Zahedi, 2011) - people from some Asian cultures are reluctant to give managers bad news - while those from other cultures may exaggerate it. Teambuilding issues can become more problematic as teams are comprised of people from a mix of these cultural types (Lisak \& Erez, 2015). Effective cross-cultural team-building is essential to benefiting from the potential advantages of cultural diversity in the workplace. It is very important to consider the problems, which come from the multiculturality. Problems with risk culture are often blamed for organisational difficulties but, until now, there was very little practical advice around on what to do about it. The objective of this study was to obtain in-depth understanding of the concept of necessary competences, which could ensure effective work in multicultural organisations based on different risks, which can occur in practice. The competences are understood in this paper as a set of knowledge, skills and attitudes as this approach is currently dominant in literature. The obtained research results, collected through the performance of the qualitative interviews, will enable to find out, which competences are needed in order to manage the multicultural company in a more effective way.

\section{LITERATURE REVIEW}

There are a lot of risks in the functioning of the organisation (market, financial, legal, ecological, political), however taking into consideration the possibility of mixing people from different regions in the world, a cultural risk is dominant. People from different cultures present different approaches to work and they can understand many things in a different manner. That is why 'cultural risk is a journey with no end', which means that it cannot be compared with the risk process in general. It can be never completed. The success of international staff is assumed by psychological features, which cannot be modified, but they can be strengthened in order to be a strong side when working in intercultural organisation (Przytuła, 2011). That is why risk culture requires awareness at all levels of the company (Laycock, 2014), both personal and organisational. The state-of-the-art clearly shows that the main problems with the staff in the multicultural organisations are the following: lack of openness, lack of speaking in an understanding way, inability of speaking language of a country, lack of punctuality, different facial expression, etc. (Bucker \& Beerlage, 2017; Chmielewska-Muciek, 2017; Fitzsimmons, 2013; Korzilius, Yeo \& Pang, 2017; Panagiotis, 2012; Przytuła, 2011).

Companies from all over the world have its branches in Poland. Some of the Polish firms have changed as well - foreign investors become managers and administrative directors. Opening the borders made it easy for companies to entrance on new markets, 
especially the European Union ones. Generally, international corporations charge experienced specialists with assistance at creation and opening of new branches. More and more organisations have contacts with representatives of different countries, societies and religion associations that serve as a sufficient base to launch cooperation.

In an increasing number of occupations, a large influx of foreigners (mainly Ukrainians) is observed (Skoczyńska-Prokopowicz, 2018; Zubik, 2014). The interest in foreigners is mainly related to building industry, construction and production, but employers are looking for specialists in the IT industry as well, because of an insufficient number of candidates on the domestic market.

Therefore, many risks may occur, mainly resulting from the lack of knowledge of different cultures. The risks related to the management and working in multicultural organisations in Poland are presented in Table 1.

In order to minimise or avoid cultural risks, the organisation must be interculturally competent (Brünnemann, 2013; Hammer, 2009; Jackson, 2015). Ideally, the whole organisation should become interculturally competent. However, this of crucial importance to managers and employees in two important respects (1) they need to be interculturally competent to manage intercultural environments effectively and helping employees understand culture better and (2) develop the knowledge, skills and attitudes to operate effectively in an increasingly intercultural workplace (Lara \&Salas-Vallina, 2017).

Organisations have a 'culture' of policies, procedures, programmes, and processes, and incorporate certain values, beliefs, assumptions, and customs (Zalina, Abdullah \& Ismailc, 2016). Organisational cultures largely echo mainstream culture in its sense of time orientation, perception, and use of time. An organisational culture may not naturally lend itself to cultural competence, so that is where skill building comes in. A culturally competent organisation brings together knowledge about different groups of people - and transforms it into standards, policies, and practices that make everything work (Lara et al., 2017). There are some key elements that contribute to a system's ability to become more interculturally competent (Alegre \& Chiva, 2013). In organisations intercultural competence would be characterised by: valuing diversity among staff; self-assessment; institutional cultural knowledge; adapting service delivery to reflect an understanding of diversity; openness and respect for diverse staff; a culturally diverse workforce; consciousness and management of difference; routine monitoring and evaluation of impact of policies and practices on cultural and ethnic groups (Davis \& Cho, 2005; Lloyd \& Hartel, 2010; Zimmermann, 2010).

The delivery of interculturally competent services cannot be divorced from the question of opening up the institution, as a starting point for staff to develop intercultural competence. 
Table 1. Risks occurring in multicultural organisations in Poland in today's economy

\begin{tabular}{|c|c|}
\hline Behaviour & Risk \\
\hline $\begin{array}{l}\text { Difference of intentions - people have in mind one thing, but } \\
\text { they say something, which does not correspond with the first } \\
\text { thought. }\end{array}$ & $\begin{array}{l}\text { Language misunderstandings } \\
\text { and lack of clarity in communi- } \\
\text { cation (Kostrzyńska, 2018) }\end{array}$ \\
\hline $\begin{array}{l}\text { Employer's care for adapting the working conditions to the needs } \\
\text { of the others - it must be reflected in knowledge of legal aspects. } \\
\text { Modern work methods, such as brainstorm, may not be stimulat- } \\
\text { ing for representatives of high-context cultures, who do not work } \\
\text { in the same way as representatives of low-context cultures. }\end{array}$ & $\begin{array}{l}\text { Different interpretation of the } \\
\text { same situations; individualism } \\
\text { vs. collectivism; unintentional } \\
\text { offending (Kostrzyńska, 2018) }\end{array}$ \\
\hline $\begin{array}{l}\text { Lack of education of Polish supervisors in managing international } \\
\text { teams - supervisors will often over-manage and get bossy. That } \\
\text { will rankle the employees and the negative cycle is reinforced. }\end{array}$ & $\begin{array}{l}\text { Decrease in efficiency, decrease } \\
\text { employee morale (Rogowski, } \\
\text { 2015) }\end{array}$ \\
\hline $\begin{array}{l}\text { Differences in management in Poland and other countries - for } \\
\text { example Asian companies are not interested in participating and } \\
\text { organising external training, because they all have developed } \\
\text { procedures, technology and knowledge about their industry. }\end{array}$ & $\begin{array}{l}\text { Ethnocentrism, individualism vs. } \\
\text { collectivism, creation of sub- } \\
\text { groups (Berłowski, 2014) }\end{array}$ \\
\hline $\begin{array}{l}\text { Complaint about bureaucracy and public sector employees' atti- } \\
\text { tude by foreigners - they are also confronted with incompe- } \\
\text { tence and complicated procedures in a system. }\end{array}$ & $\begin{array}{l}\text { Decrease in efficiency, decrease } \\
\text { employees' morale, language } \\
\text { misunderstandings and lack of } \\
\text { clarity in communication } \\
\text { (Bilicka, Paszkowska-Rogacz \& } \\
\text { Stawiany-Marchwicka, 2006) }\end{array}$ \\
\hline $\begin{array}{l}\text { Usual requirement to communicate informally with all the work- } \\
\text { mates, regardless of their position in global companies having } \\
\text { their branch in Poland - the Poles are not used to it and they } \\
\text { prefer rather formal contact with management staff and they } \\
\text { are afraid to break this barrier. }\end{array}$ & $\begin{array}{l}\text { Unintentional offending, the } \\
\text { sense of shame, creation of sub- } \\
\text { groups (Wach, 2010) }\end{array}$ \\
\hline $\begin{array}{l}\text { Problem with acceptance of existence of different culture or reli- } \\
\text { gion in a working place - this prejudice is a result of false percep- } \\
\text { tion of so called 'strangers', 'others', 'different'. These reactions } \\
\text { of distaste, disapproval or hostility are most often the results of } \\
\text { ignorance. Lack of acquaintance of culture, tradition, religion or } \\
\text { language of other nations, communities or groups leads to nega- } \\
\text { tive behaviours. }\end{array}$ & $\begin{array}{l}\text { Creation of subgroups, stereo- } \\
\text { types, ethnocentrism } \\
\text { (Wojtulewski, 2016) }\end{array}$ \\
\hline $\begin{array}{l}\text { Different perception of time - monochronic cultures, such as } \\
\text { Germany and Poland value punctuality and keeping to sched- } \\
\text { ules. In polychronic cultures, such as the Middle East or Latin } \\
\text { America, maintaining relationships and socializing is more im- } \\
\text { portant than the schedule. Differences in concepts of time can } \\
\text { pose challenges for multinational companies in Poland. }\end{array}$ & $\begin{array}{l}\text { Project delays, different inter- } \\
\text { pretation of the same situa- } \\
\text { tions, ethnocentrism (Kosiu, } \\
\text { Troncy \& Golzhauser, 2005) }\end{array}$ \\
\hline $\begin{array}{l}\text { Implementation of various solutions without taking into account } \\
\text { Polish specificity by many international organisations having } \\
\text { their branches in Poland. }\end{array}$ & $\begin{array}{l}\text { Decrease in efficiency, different } \\
\text { interpretation of the same situ- } \\
\text { ations, creation of subgroups } \\
\text { (Gajek, 2009) }\end{array}$ \\
\hline
\end{tabular}

Source: own elaboration. 


\section{MATERIAL AND METHODS}

Due to the fact that the multicultural organisations are exposed to many risks coming from different cultures, the authors designed the questionnaire (see in Annex 1), which aimed at verifying, which competences are needed in order to minimise or even eliminate potential risks.

Therefore, the main research question was: What competences should be acquainted by the staff from multicultural organisations in order to be more effective in daily work?

The questionnaire included eight (8) parts, which were strongly related to the issue of the management and functioning in multicultural environment. The questionnaire was directed to the following target groups (Figure 1):

- Managerial staff from multicultural organisations;

- Employees working at lower levels in multicultural organisations;

- Other individual people, who had the contact in the past with multicultural organisations, and who faced the problem of risks coming from the culture diversity.

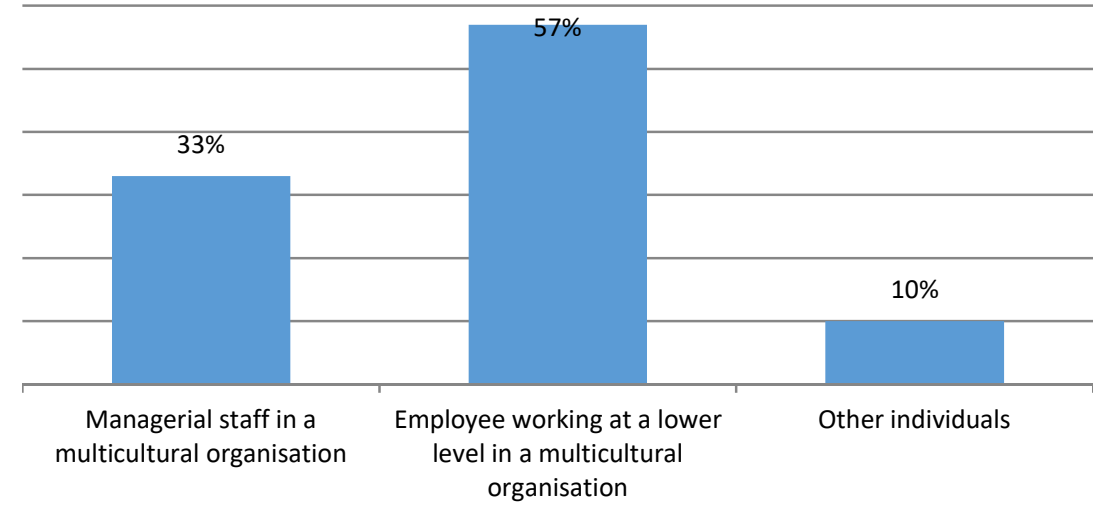

Figure 1. Target group taking part in the research between 2018 and 2019 Source: own elaboration.

The questionnaire was directed to thirty (30) representatives of multicultural companies from Poland. The authors performed face-to-face interviews with the use of previously prepared questionnaire. All competences were evaluated by using the scale, where ' 4 ' means that competences are very important to be achieved, ' 3 ' means that competences are important to be achieved, ' 2 ' means that competences can be achieved, but they do not seem to be significant, and ' 1 ' means that competences are unnecessary to be achieved. All items also included a possibility to choose the answer 'hard to say', if an interviewee had a problem in deciding. For data processing, the program IBM SPSS Statistics 22 was used.

The data, which were collected in the study achieved an overall norm of between 15 and 60 participants for qualitative interviews within Organisational \&Work studies. In the opinion of Marshall, Cardon, Poddar \& Fontenot (2013) "this norm indicates that the number of participants likely to be considered sufficient is both more varied and greater than 
the 15-30 participants suggested by empirically justified guidance, and all expert opinions reviewed other than Adler \& Adler (2012) who advise between 12 and 60" (p. 34).

\section{FINDINGS AND DISCUSSION}

The questionnaire results show that the majority of interviewees agreed that competences listed in the questionnaire are 'very important' and 'important'. Only a few of them answered that those competences are 'not important' or 'unnecessary'. The answer 'hard to say' was chosen only a few times. Detailed analysis is presented below.

To define the concepts: "culture", "cultural awareness", "culture sensitivity" and "culture shock"

To recognise the most popular cultures oocurring in Europe

To analyse the main differences between own and other cultures

To distinguish between cultural differences of the society and differences of the individuals (case studies)

To get familiar with interesting models of culture, i.e. the Iceberg Model of Culture, Hofstede's Cultural Dimensions

Theory, Milton Bennett's Cultural Sensitivity Model

\begin{tabular}{|c|c|c|c|c|c|c|}
\hline & & $0 \%$ & $20 \%$ & $40 \%$ & $60 \%$ & $80 \%$ \\
\hline Very important & IImportant & - Not important & 믈 Not & mportant & $\square \mathrm{Ha}$ & $a y / N A$ \\
\hline
\end{tabular}

Figure 2. Cross cultural awareness

Source: own elaboration.

The interviewees acknowledged that according to them, the least valuable competence is 'to get familiar with interesting models of culture, i.e. the Iceberg Model of Culture, Hofstede's Cultural Dimensions Theory, Milton Bennett's Cultural Sensitivity Model'. It received $23 \%$ of the 'not important' and $13 \%$ of 'unnecessary' answers. This competence had also $27 \%$ 'hard to say' answers. Taking into account different respondents, it turned out that managerial staff agreed that very important or important are the following competences: to recognise the most popular cultures occurring in Europe and to distinguish between cultural differences of the society and of the individuals. Similarly, employees from lower level also agreed that the most important competence is to know the differences between societies and the individuals as it improved the effectiveness of work between multicultural staff in the organisation.

It comes from the fact that the respondents are not interested in scientific aspects of culture. They prefer knowing practical aspects, which can be met in everyday work in the multicultural organisations. It can be observed that the competence to analyse the main differences between own and other cultures' was assessed as the most important. It can result from the fact that many people identify the own culture with the other ones, not seeing any big differences. Therefore, many conflicts or misunderstanding can 
occur. It is confirmed in literature, among others, by Chaney (2005), Milfont (2012) or Gut, Wilczewski \& Gorbaniuk (2017).

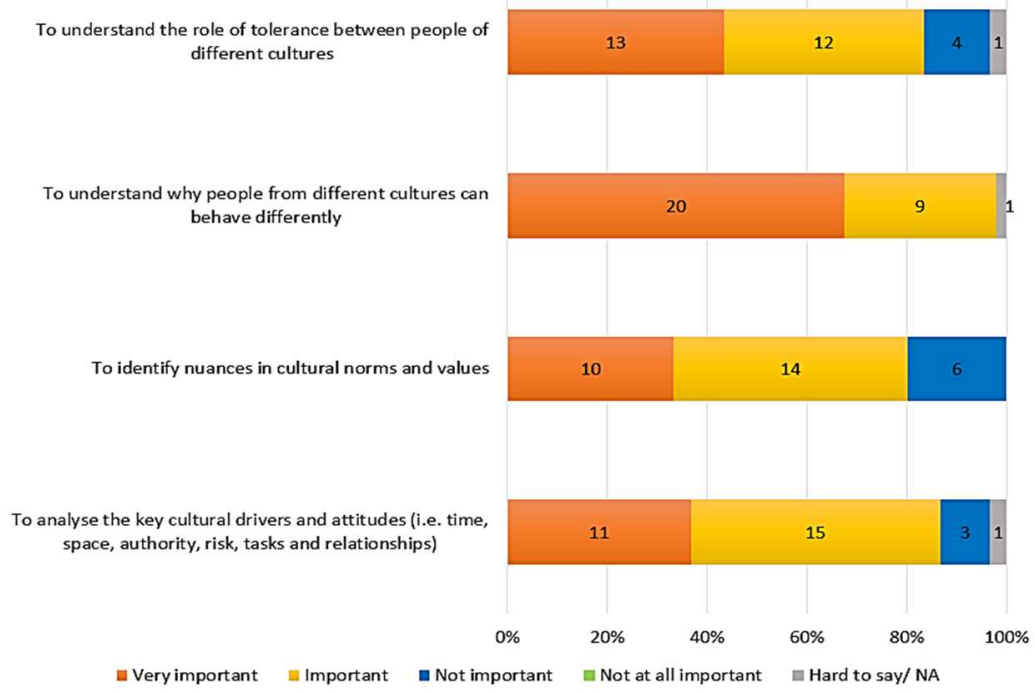

Figure 3. Understanding different cultures

Source: own elaboration.

In Part 2, the interviewees were obliged to answer, which competences are desirable to better understand other cultures. The vast majority of the respondents recognized that all the competences are important. The highest percentage (70\% 'as very important' and $30 \%$ as 'important') were related to the competence 'to understand why people from different cultures can behave differently'. Such responses can show that the respondents relate the competences to practical situations, which can be met in everyday life. Employees from lower level highlighted that crucial is to recognise and understand why people from different cultures behave differently. If it is recognised, it is then easier to predict the behaviour of the colleagues from the working organisation. Managerial staff underlined that the employees should understand the role of tolerance between people of different cultures. It was the core competence for these respondents as they think that without being tolerance, the atmosphere in the workplace is not good.

Based on the results in Part 2, it can be seen that among the interviewees the most important is to understand the behaviour of culturally different people and understand the role of tolerance in order to improve their work in the organisation. In literature it is confirmed, among others, in the works of Serin (2017) or Spencer-Rodgers, Williams \& Peng (2010). None of the competences was considered as 'unnecessary' in this module.

In Figure 3, the respondents were asked questions about competences that can support understanding and overcoming cultural stereotypes. The most important competence turned out to be 'to identify possible cultural biases, prejudices and beliefs' (both for managerial staff and employees from lower level in a multicultural organisation), which obtained $40 \%$ as 'very important' and $50 \%$ as 'important' answers. It came from 
the fact that people are very sensitive when comparing different religions or beliefs. Unfortunately, it often results from the lack of knowledge on the issue (Matusitz, 2012). The least important competence in Figure 3 (23\% as 'not important', 3\% as 'unnecessary') was related to 'to define the term cultural stereotypes'. Employees from lower level underlined that all competences, which concern the definitions are unnecessary, because it is crucial to be able to do, and not to know.

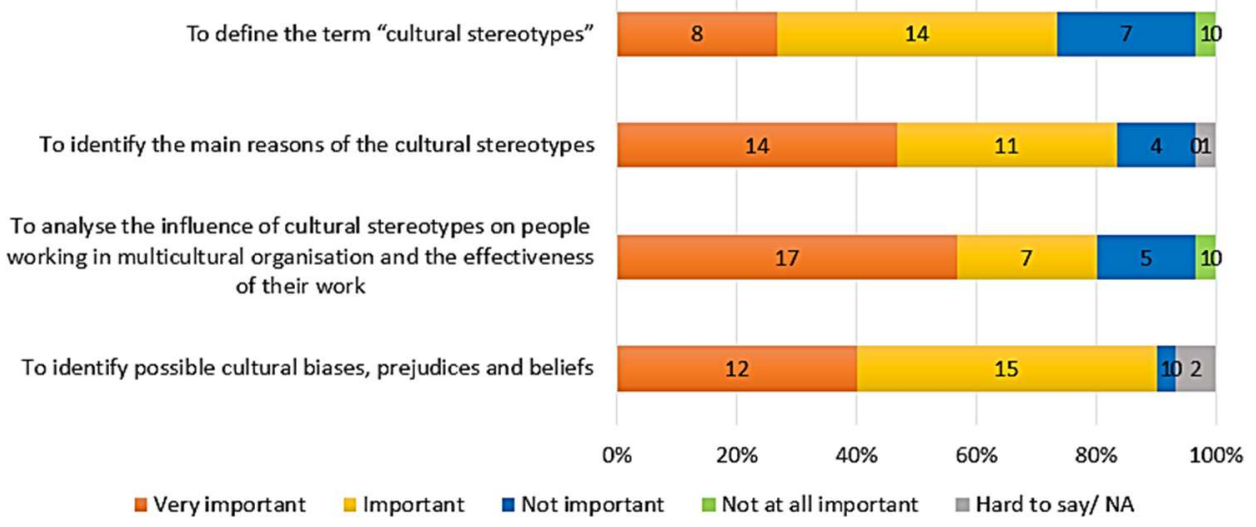

Figure 4. Stereotypes

Source: own elaboration.

The results clearly indicate that the respondents considered understanding and breaking stereotypes as crucial in improving cooperation in the organisation. The choice of the least important competence may suggest that the majority of respondents know what cultural stereotypes are, and do not need further development of this competence, but rather focus on their impact on cooperation between employees.

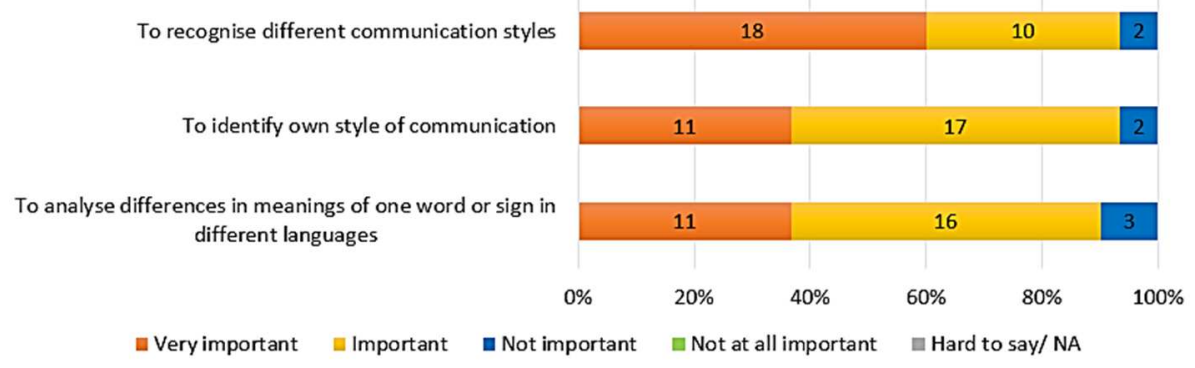

Figure 5. Communication

Source: own elaboration.

Figure 4 focused on competences that can support to improve multicultural communication. Most of the answers (92\%) were perceived as answers 'very important' and 'important' in the entire survey, which allows to conclude that communication was recognized as the most important factor that can improve cooperation between employees and 
minimize risks in multicultural organisations. Decisively the employees from lower level stated that the most important is the competence 'to analyse differences in meanings of one word or sign in different languages'. It is necessary, because the same word can have different meaning in different languages. On the other hand, managerial staff agreed that, apart from differentiating the meaning of words or signs, it is also supportive in work to recognise different communication styles as not all the people have the same style, the same level of speed and the same level of effectiveness.

The responses should not be surprising as in the literature many publications (Ochieng \& Price, 2010; Otter \& Emmitt, 2008) indicate the importance of the communication in multicultural environments. What can be worrying, Polish respondents did not take into account the importance of differentiating communication styles, which can be crucial in everyday contacts of multicultural teams (Gilley, Gilley \& McMillan, 2009).

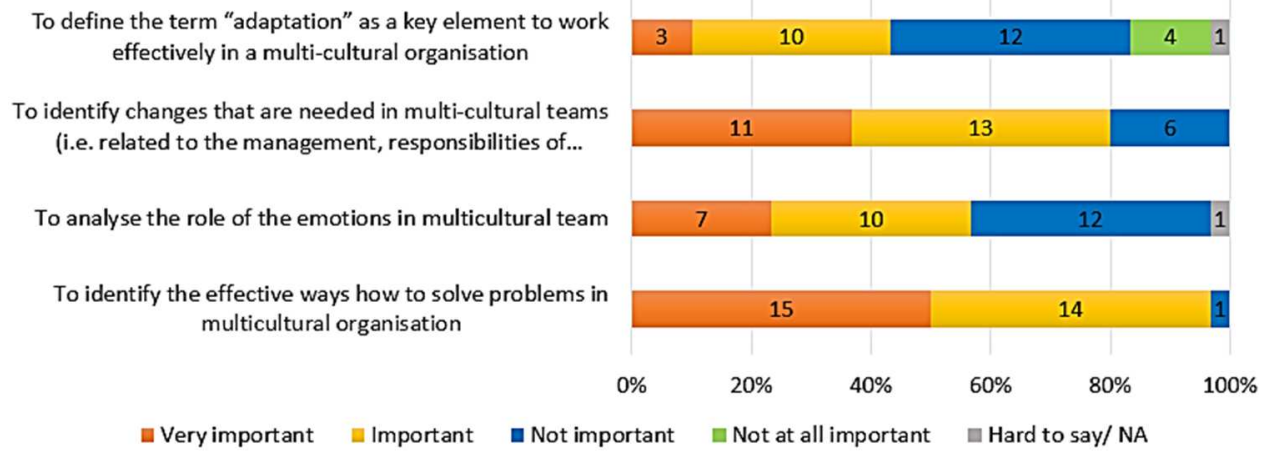

Figure 6. Teamwork and social integration

Source: own elaboration.

In Figure 6, the respondents were asked about competences that may improve teamwork and social integration in the multicultural organisation. In the opinion of the respondents - both managerial staff and employees from lower level in multicultural organisation, the crucial competence was 'to identify the effective ways how to solve problems in multicultural organisation'. Solving problems in cultural diversity of the organisation in indeed one of the crucial elements to ensure effectiveness in works (Velten \& Lashley, 2018).

The interviewees (especially employees from lower level) identified the competence 'to define the term adaptation as a key element to work effectively in a multi-cultural organisation' as the least important competence. Similarly to the responses of the respondents in previous Parts, they did not focus on theory, but practical aspects.

In Figure 7, the interviewees had to indicate, which competences, related to leadership and hierarchy, influence the quality of work in the multicultural organisation. Almost all of the competences obtained more than $80 \%$ of 'very important' and 'important' answers. Only the first competence ('to analyse how to introduce changes in the organisation') obtained $27 \%$ of 'very important' and $47 \%$ 'important' answers and this answer was mainly given by the managerial staff.

According to the respondents, the least important competence was 'to analyse how to introduce changes in the organisation'. $13 \%$ of them indicated this competence 
as 'not important', and $10 \%$ of them (only employees from lower level) as 'unnecessary'. It is surprising, because the management change is one of the most important factors in the organisation (Kotter, 2011).

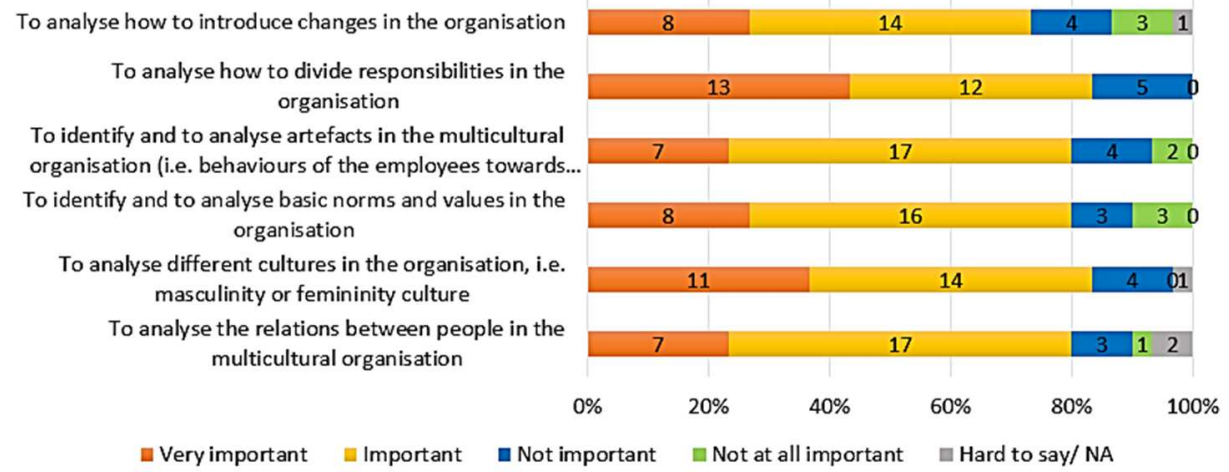

Figure 7. Leadership and hierarchy

Source: own elaboration.

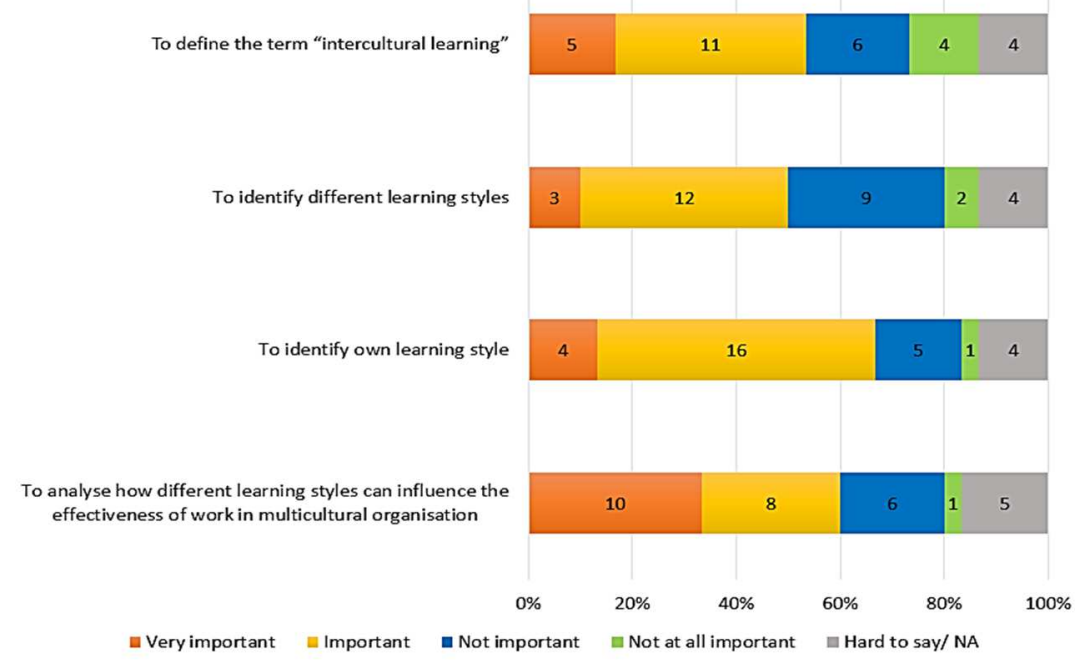

Figure 8. Learning styles

Source: own elaboration.

Figure 8 aimed at examining, which competences are important to better recognise learning styles. The most important competence turned out to be 'to analyse how different learning styles can influence the effectiveness of work in multicultural organisations' with the score of $33 \%$ of 'very important' and $27 \%$ of 'important' answers.

As the least important competence - 30\% 'not important' was indicated 'to identify different learning styles'. Here, it was observed that mainly employees from lower level decided in this way. It clearly shows that the respondents highlighted their own learning 
style, not the styles of the co-employees. It can cause the problem related to the completion of tasks in the time given, to keeping deadlines and also to the achievement of the high quality of the results (La Fever, 2010).

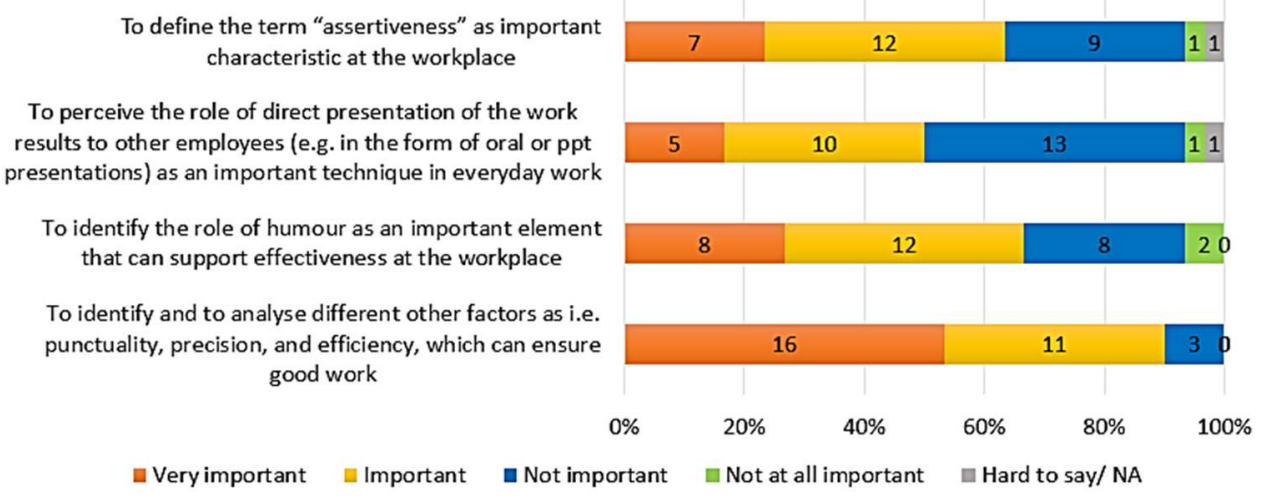

Figure 9. Qualities in the working place

Source: own elaboration.

Figure 9 focused on the competences that may improve the quality of work in the working place in multicultural organisations. The most valuable competences was 'to identify and to analyse different other factors as i.e. punctuality, precision, and efficiency, which can ensure good work' with the score of $53 \%$ as 'very important' and $37 \%$ as 'important'. This competence was important both managerial staff and employees from lower level in a multicultural organisation.

It can show that the respondents take into account such elements like punctuality, precision or efficiency. On the other hand. The interviewees indicated the competence 'to perceive the role of direct presentation of the work results to other employees (e.g. in the form of oral or ppt presentations) as an important technique in everyday work' as the least important competence, which can mean that they prefer direct contacts between people, not concentrating on technical issues of working in multicultural organisation.

\section{CONCLUSIONS}

The need for intercultural competence has become a necessity for the organisations. In the midst of unprecedented demographic changes most countries now have residents, workers and citizens originating from countries all over the world, and to all intents and purposes are multicultural, some to a greater extent than others, but becoming increasingly so. The need to understand the role of culture in intercultural interaction and to be aware of cultural risks in the organisation is growing, and in light of globalisation intercultural competence becomes even more crucial. There is increasing awareness, if not knowledge of cultural difference among staff in different organisations. The effect of the lack of competence can be far reaching. The relationships between employer / employee or employee / employee are affected when there is misunderstanding or lack of 
knowledge about each other's expectations. There is need to understand why some people from different cultures are reticent and will not ask for help or participate in discussions that involve being critical of employers or employees in the institution, even if it is constructive. A lack in understanding these differences is often one of the major intercultural problems that could arise in business negotiations.

This study aimed at identifying competences, which seem to be crucial in order to work more effectively in the multicultural organisations and to get familiar with the diversity coming from the staff representing different cultures. Based on conducted study we have found out that for the participants of the interviews it is very important to know different aspects related to culture, which will contribute to the effectiveness of work. Taking into account different types of the respondents, it can be stated that managerial staff paid more attention to managerial competences and theoretical aspects. As opposite, employees from lower level focused mainly on competences, which can be used in direct contacts with the colleagues from different cultures. They were not interested in acquiring competences, which are theoretical, but these ones, which can be used in everyday life in working conditions.

The article is of not only theoretical, but mainly applicative character, because based on the results it is possible to develop a training for the intercultural staff, which will support them in coping in multicultural environment. However, the study was limited to multicultural organisations from Poland, so in such a way they should not be generalised.

The next step of the research should be to compare the results with the results from different countries in order to see similarities and differences.

\section{REFERENCES}

Adler, P., \& Adler, P. (2012). Expert Voice. In S.E. Baker \& R. Edwards, How Many Qualitative Interviews Are Enough? (pp. 8-11). National Centre for Research Methods Review Discussion Paper. Retrieved from http://eprints.ncrm.ac.uk/2273/ on May 9, 2015.

Alegre, J., \& Chiva, R. (2013). Linking Entrepreneurial Orientation and Firm Performance: The Role of Organizational Learning Capability and Innovation Performance. Journal of Small Business Management, 51(4), 491-507. https://doi.org/10.1111/jsbm.12005.

Angouri, J., \& Glynos, J. (2009). Managing Cultural Difference and Struggle in The Context of Multinational Corporate Workplace: Solution or Symptom? Working papers in Ideology and Discourse Analysis, 26, 3-9.

Berłowski, P. (2014). Kultura Dużego Przyspieszenia w Firmie Siemens. Personel i Zarzqdzanie, 7, 26-29.

Besley, T., \& Peters, M.A. (2012). Interculturalism, Education and Dialogue. Bern: Peter Lang.

Bikmen, N., \& Sunar, D. (2013). Difficult Dialogs: Majority Group Members' Willingness to Talk about Inequality with Different Minority Groups. International Journal of Intercultural Relations, 37(4), 467-476. https://doi.org/10.1016/j.ijintrel.2012.11.002

Bilicka, D., Paszkowska-Rogacz, A., \& Stawiany-Marchwicka, M. (2006). European Intercultural Workplace: Poland. Retrieved from: http://immi.se/eiw/texts/National_Report_Poland.pdf on June 10, 2019.

Brünnemann, K. (2013). The Strategic Importance of Intercultural Competency for Project Managers for the 21st Century. Working Paper Series by the University of Applied Sciences bfi Vienna, 79.

Chaney, L. (2005). Intercultural Business Communication, 4th ed. Englewood Cliffs, NJ: Prentice-Hall.

Chmielewska-Muciek, D. (2017). Diagnosis of Communication Context in Companies. Annales Universitatis Mariae Curie-Skłodowska, 51(3), 7-15. https://doi.org/10.17951/h.2017.51.3.7 
Choi, J.N. (2006). Multilevel and Cross-Level Effects of Workplace Attitudes and Group Member Relations on Interpersonal Helping Behaviour. Human Performance, 19(4), 383-402. https://doi.org/10.1207/s15327043hup1904_4

Davis, N., \& Cho, M.O. (2005). Intercultural Competence for Future Leaders of Educational Technology and its Evaluation. Interactive Educational Multimedia, 10, 1-22.

Fitzsimmons, S. (2013). Multicultural Employees: A Framework for Understanding How They Contribute to Organizations. Academy of Management Review, 38, 525-549. doi: 10.5465/amr.2011.0234

Gajek, K. (2009). Dynamika Procesów Wielokulturowych w Organizacji. Studium Przypadku. Problemy Zarzq̨dzania, 7, 158-171.

Gilley, A., Gilley, J.W. \& McMillan, H.S. (2009). Organizational Change: Motivation, Communication, and Leadership Effectiveness. Performance Improvement Quarterly, 21(4), 75-94. doi: 10.3763/aedm.2008.0072

Gut, A., Wilczewski, M., \& Gorbaniuk, O. (2017). Cultural Differences, Stereotypes and Communication Needs in Intercultural Communication in a Global Multicultural Environment. The Employees' Perspective. Journal of Intercultural Communication, 43(1), 1-20.

Hammer, M.R. (2009). The Intercultural Development Inventory: An Approach for Assessing and Building Intercultural Competence. In M.A. Moodian (Ed.), Contemporary Leadership and Intercultural Competence: Exploring the Cross-Cultural Dynamics within Organizations (pp. 203-217). Thousand Oaks, CA: Sage.

Jackson, J. (2015). Becoming Interculturally Competent: Theory to Practice in International Education. International Journal of Intercultural Relations, 48, 91-107. https://doi.org/10.1016/j.ijintrel.2015.03.012

Korzilius, H., Bücker, J.J.L.E., \& Beerlage, S. (2017). Multiculturalism and Innovative Work Behaviour: The Mediating Role of Cultural Intelligence. International Journal of Intercultural Relations, 56, 13-24. https://doi.org/10.1016/j.ijintrel.2016.11.001

Kosiu, K., Troncy, C., \& Gölzhäuser, J. (2005). Time Perception in France, Germany and Poland. Eurolimes, 1(5), 1-10.

Kostrzyńska, A. (2018). Wielokulturowość w Biznesie i Organizacji, Eksport.pl. Retrieved from: https://eksport.pl/2018/02/23/wielokulturowosc-biznesie-organizacji/ on June 10, 2019.

Kotter, J. (2011). Change Management vs. Change Leadership - What's the Difference? Retrieved from: www. forbes.com/sites/johnkotter on May 24, 2019.

La Fever, M. (2010). Cross-Cultural Learning Styles. In: Clauss-Ehler C.S. (eds) Encyclopedia of CrossCultural Psychology,Boston, MA: Springer, 286-287, doi: 10.1007/978-0-387-71799-9

Lahdesmaki, T., \& Wagener, A. (2015). Discourses on Governing Diversity in Europe: Critical Analysis of the White Paper on Intercultural Dialogue. International Journal of Intercultural Relations, 44, 13-28. https://doi.org/10.1016/j.ijintrel.2014.11.002

Lara, F.J., Palacios-Marques, D. \& Devece, C.A. (2012). How to Improve Organizational Result through Knowledge Management in Knowledge-Intensive Business Services. The Service Industries Journal, 32(12), 1853-1863.

Lara, F.J., \& Salas-Vallina, A. (2017). Managerial Competencies, Innovation and Engagement in SMEs: The Mediating Role of Organisational Learning. Journal of Business Research, 79, 152-160. https://doi.org/10.1016/j.jbusres.2017.06.002

Laycock, D. (2014). Religious Liberty and the Culture Wars. University of Illinois Law Review, 3, 839-880.

Lisak, A., \& Erez, M. (2015). Leadership Emergence in Multicultural Teams: The Power of Global Characteristics. Journal of World Business, 50(1), 3-14. https://doi.org/10.1016/j.jwb.2014.01.002 
Lloyd, S. \& Hartel, C. (2010). Intercultural Competencies for Culturally Diverse Work Teams. Journal of Managerial Psychology, 25(8), 845-875. https://doi.org/10.1108/02683941011089125.

Marshall, B., Cardon, P., Poddar, A. \& Fontenot, R. (2013). Does Sample Size Matter in Qualitative Research: A Review of Qualitative Interviews in IS Research. Journal of Computer Information Systems, 54, 11-22.

Matusitz, J. (2012). Relationship between Knowledge, Stereotyping, and Prejudice in Interethnic Communication. Revista de Turismo y Patrimonio Cultural, 10(1), 89-98. https://doi: 10.25145/j.pasos.2012.10.008

Milfont, T. L. (2012). Cultural Differences in Environmental Engagement. In S.D. Clayton (Ed.), Oxford library of psychology. The Oxford handbook of environmental and conservation psychology, 181200. New York: Oxford University Press. http://dx.doi.org/10.1093/oxfordhb/9780199733026.013.0011

Ocheng, E., \& Price, A.D.F. (2010). Factors Influencing Effective Performance of Multi-Cultural Construction Project Teams, Proceedings 26th Annual ARCOM Conference. Leeds, UK., 2, 1159-1167.

Otter, A. \& Emmitt, S. (2008). Design Team Communication and Design Task Complexity: The Preference for Dialogues. Architectural Engineering and Design Management, 4(2), 121-129. https://doi: 10.3763/aedm.2008.0072

Panagiotis, M. (2012). An Analysis of the Cultural Differences between Leadership. The Case of Greece and Germany. Seminar paper.

Przytuła, S. (2011). Problemy Wielokulturowości w Korporacjach Międzynarodowych. Problemy Zarzq̨dzania, 9(4), 26-42.

Rogowski, W. (2015). Przyczyny Upadłości Polskich Przedsiębiorstw - Aspekt Teoretyczny. Studia i Prace. Kolegium Zarzq̨dzania i Finansów, 143, 119-154.

Ryan, L. (2016). The Five Most Common Culture Problems and Their Solutions, Forbes. Retrieved from: https://www.forbes.com/sites/lizryan/2016/08/13/the-five-most-common-cultureproblems-and-their-solutions/\#59b4930c9bed on June 10, 2019.

Serin H. (2017). Teaching about Respect and Tolerance with Presentations on Cultural Values. International Journal of Social Sciences \& Educational Studies, 3(4), 174-176. https://doi.org/10.23918/ijsses.v3i4p174

Skoczyńska-Prokopowicz, B. (2018). Foreign Labour Migration of Ukrainians to Poland: Statistical Research from the Perspective of Ukrainian Studies, Zeszyty Naukowe Politechniki Ślqaskiej, Organizacja I Zarzqdzanie, 122, 195-203. https://doi.org/10.29119/1641-3466.2018.122.21

Spencer-Rodgers, J., Williams, M.J., \& Peng, K. (2010). Cultural Differences in Expectations of Change and Tolerance for Contradiction: A Decade of Empirical Research. Personality and Social Psychology Review, 14(3), 296-312. doi: 10.1177/1088868310362982

Velten, L. \& Lashley, C. (2018). The Meaning of Cultural Diversity Among Staff as It Pertains to Employee Motivation. Research in Hospitality Management, 7(2), 105-113. doi: 10.1080/22243534.2017.1444718

Wach, K. (2010). Doing Business in Poland. Socio-Cultural Aspects. Retrieved from: https://spu.fem.uniag.sk/Elena.Horska/ceb/CEI_WACH_05_doing_business_in_Poland.pdf on June 10, 2019.

Wilk-Wos, Z. (2010). The Role of Intercultural Dialogue in the EU Policy. Journal of Intercultural Management, 2(1), 78-88.

Wojtulewski, R. (2016) Akceptacja Inności - Spostrzeganie Odmienności Narodowej Studentów z Ukrainy wśród Studentów Uczelni Krakowskich. Państwo i Społeczeństwo, 2016 (XVI), 1, 149-174. 
Yeo, S.L., Pang, A. (2017). Asian Multiculturalism in Communication: Impact of Culture in the Practice of Public Relations in Singapore. Public Relations Review, 43(1), 112-122. https://doi.org/10.1016/j.pubrev.2016.10.014

Zahedi, F. (2011). The Challenge of Truth Telling Across Cultures: A Case Study. Journal of Medical Ethics and History of Medicine, 4(11), 2-9.

Zalina, I., Abdullah, F., \& Ismailc, A. (2016). International Business Competence and Small and Medium Enterprises, Procedia - Social and Behavioral Sciences, 224, 393-400, https://doi.org/10.1016/j.sbspro.2016.05.402.

Zimmermann, K. (2010). Intercultural Competence as a Success Factor of Virtual Multicultural Teams: A Case Study on the Team Effectiveness of Global HR Teams. Jyväskylä: Universidade de Jyväskylä.

Zubik, A. (2014). Suthasna Trudova Mihracia Ukraintskogo Naselenia w Polshu. Ekonomithna ta Socialna Geografia. Naukovi Zapiski, 1, 111.

\section{Appendix 1}

\begin{tabular}{|c|c|}
\hline \multicolumn{2}{|c|}{ Module 1: } \\
\hline 1 & $\begin{array}{l}\text { To define the concepts: "culture", "cultural awareness", "culture sensitivity" and "culture } \\
\text { shock" }\end{array}$ \\
\hline 2 & To recognise the most popular cultures occurring in Europe \\
\hline 3 & To analyse the main differences between own and other cultures \\
\hline 4 & $\begin{array}{l}\text { To distinguish between cultural differences of the society and differences of the individ- } \\
\text { uals (case studies) }\end{array}$ \\
\hline 5 & $\begin{array}{l}\text { To get familiar with interesting models of culture, i.e. the Iceberg Model of Culture, Hof- } \\
\text { stede's Cultural Dimensions Theory, Milton Bennett's Cultural Sensitivity Model }\end{array}$ \\
\hline \multicolumn{2}{|r|}{$\begin{array}{l}\text { Module 2: } \\
\text { UNDERSTANDING DIFFERENT CULTURES } \\
\text { Which competences are important to understand better different cultures? }\end{array}$} \\
\hline 1 & To understand the role of tolerance between people of different cultures \\
\hline 2 & To understand why people from different cultures can behave differently \\
\hline 3 & To identify nuances in cultural norms and values \\
\hline 4 & $\begin{array}{l}\text { To analyse the key cultural drivers and attitudes (i.e. time, space, authority, risk, tasks } \\
\text { and relationships) }\end{array}$ \\
\hline \multicolumn{2}{|r|}{$\begin{array}{l}\text { Module 3: } \\
\text { STEREOTYPES } \\
\text { Which competences are supportive to understand and break cultural stereotypes? }\end{array}$} \\
\hline 1 & To define the term "cultural stereotypes" \\
\hline 2 & To identify the main reasons of the cultural stereotypes \\
\hline 3 & $\begin{array}{l}\text { To analyse the influence of cultural stereotypes on people working in multicultural or- } \\
\text { ganisation and the effectiveness of their work }\end{array}$ \\
\hline 4 & To identify possible cultural biases, prejudices and beliefs \\
\hline
\end{tabular}




\begin{tabular}{|c|c|}
\hline \multicolumn{2}{|r|}{$\begin{array}{l}\text { Module 4: } \\
\text { COMMUNICATION } \\
\text { Which competences can help to improve multicultural communication? }\end{array}$} \\
\hline 1 & To recognise different communication styles \\
\hline 2 & To identify own style of communication \\
\hline 3 & To analyse differences in meanings of one word or sign in different languages \\
\hline \multicolumn{2}{|r|}{$\begin{array}{l}\text { Module 5: } \\
\text { TEAMWORK AND SOCIAL INTEGRATION } \\
\text { Which competences may improve teamwork and social integration in multicultural organisation? }\end{array}$} \\
\hline 1 & $\begin{array}{l}\text { To define the term "adaptation" as a key element to work effectively in a multi-cultural } \\
\text { organisation }\end{array}$ \\
\hline 2 & $\begin{array}{l}\text { To identify changes that are needed in multi-cultural teams (i.e. related to the manage- } \\
\text { ment, responsibilities of employees, organisation of works) }\end{array}$ \\
\hline 3 & To analyse the role of the emotions in multicultural team \\
\hline 4 & To identify the effective ways how to solve problems in multicultural organisation \\
\hline \multicolumn{2}{|r|}{$\begin{array}{l}\text { Module 6: } \\
\text { LEADERSHIP AND HIERARCHY } \\
\text { Which competences are related to leadership and hierarchy that influence the quality of work } \\
\text { in multicultural organisation? }\end{array}$} \\
\hline 1 & To analyse how to introduce changes in the organisation \\
\hline 2 & To analyse how to divide responsibilities in the organisation \\
\hline 3 & $\begin{array}{l}\text { To identify and to analyse artefacts in the multicultural organisation (i.e. behaviours of } \\
\text { the employees towards new employees; meetings of employees outside the company } \\
\text { aimed at their better integration; other ceremonies and rituals in the organisation) }\end{array}$ \\
\hline 4 & To identify and to analyse basic norms and values in the organisation \\
\hline 5 & To analyse different cultures in the organisation, i.e. masculinity or femininity culture \\
\hline 6 & To analyse the relations between people in the multicultural organisation \\
\hline \multicolumn{2}{|r|}{$\begin{array}{l}\text { Module 7: } \\
\text { LEARNING STYLES } \\
\text { Which competences are important to know better learning styles? }\end{array}$} \\
\hline 1 & To define the term "intercultural learning" \\
\hline 2 & To identify different learning styles \\
\hline 3 & To identify own learning style \\
\hline 4 & $\begin{array}{l}\text { To analyse how different learning styles can influence the effectiveness of work in multi- } \\
\text { cultural organisation }\end{array}$ \\
\hline
\end{tabular}




\begin{tabular}{|c|c|}
\hline \multicolumn{2}{|r|}{$\begin{array}{l}\text { Module 8: } \\
\text { QUALITIES IN THE WORKING PLACE } \\
\text { Which competences may improve the quality of work in the working place in multicultural } \\
\text { organisation? }\end{array}$} \\
\hline 1 & To define the term "assertiveness" as important characteristic at the workplace \\
\hline 2 & $\begin{array}{l}\text { To perceive the role of direct presentation of the work results to other employees (e.g. } \\
\text { in the form of oral or ppt presentations) as an important technique in everyday work }\end{array}$ \\
\hline 3 & $\begin{array}{l}\text { To identify the role of humour as an important element that can support effectiveness at } \\
\text { the workplace }\end{array}$ \\
\hline 4 & $\begin{array}{l}\text { To identify and to analyse different other factors as i.e. punctuality, precision, and effi- } \\
\text { ciency, which can ensure good work }\end{array}$ \\
\hline
\end{tabular}




\section{Authors}

The contribution share of authors is equal and amounted to $50 \%$ each of them.

\section{Ludmiła Walaszczyk}

Ph.D. (2015) in Management from the Warsaw University of Technology. Since 2005 she has worked in the Strategy Innovation Department in the LUKASIEWICZ Research Network - Institute for Sustainable Technologies in Radom. Her scientific interests concern business models aspects, the multiculturality in the organisations and the relations between the entrepreneurs and local and regional authorities.

Correspondence to: Ludmiła Walaszczyk, PhD, LUKASIEWICZ Research Network - Institute for Sustainable Technologies in Radom, Pułaskiego 6/10, 26-600 Radom, Poland, e-mail: ludmila.walaszczyk@itee.radom.pl

ORCID (1) http://orcid.org/0000-0001-8022-9419

\section{Remigiusz Mazur}

Early Stage Researcher in the LUKASIEWICZ Research Network - Institute for Sustainable Technologies in Radom, Poland. His research interests comprise innovation management, foresight, cross-cultural management, international affairs, future-oriented learning methods, and use of new technologies in training methods.

Correspondence to: Remigiusz Mazur, MA, LUKASIEWICZ Research Network - Institute for Sustainable Technologies in Radom, Pułaskiego 6/10, 26-600 Radom, Poland, e-mail: remigiusz.mazur@itee.radom.pl

ORCID (1) http://orcid.org/0000-0002-5085-7083

\section{Acknowledgements and Financial Disclosure}

The article came into being within the project no. 2018-1-PL01-KA204-051056 entitled 'Cultural Risk in the Organisation in the Globalization Era - Competences vs. Reality' financed by Foundation for the Development of the Education System conducted by Ludmiła Walaszczyk as the coordinator and the international partnership in the years 2017-2019.

\section{Copyright and License}

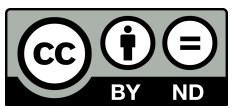

This article is published under the terms of the Creative Commons

Attribution - NoDerivs (CC BY-ND 4.0) License

http://creativecommons.org/licenses/by-nd/4.0/

\section{Published by the Centre for Strategic and International Entrepreneurship - Krakow, Poland}

Ministry of Science and Higher Education Republic of Poland
The journal is co-financed in the years $2019-2020$ by the Ministry of Science and Higher Education of the Republic of Poland in the framework of ministerial programme "Support for Scientific Journals" (WCN) on the basis of contract no. 238/WCN/2019/1 concluded on 15 August 2019. 